\title{
PERILAKU KONSUMTIF IBU RUMAH TANGGA (PERSPEKTIF SYARI'AT ISLAM)
}

\author{
Hj. A. Sukmawati Assaad \\ Fakultas Syariah Institut Agama Islam Negeri (IAIN) Palopo \\ Email : hj.a.sukma@iainpalopo.ac.id
}

\begin{abstract}
Indonesia's economic growth in the developed and developing carry capita income of Indonesia's population also increased, causing living standards increasingly prosperous population. It is affected by the person's shopping behavior patterns including housewives as a family financial management, in addition to the shopping places are comfortable and provide all the needs of consumers influence consumer behavior. In Islamic Sharia, one of the functions treasure as jewelry, treasure the jewelry world are only temporary and for that reason, as a Muslim should be able to utilize the property as well as possible to worship Allah Swt.
\end{abstract}

Keywords: Consumer Behaviour, Housewife, Islamic Sharia

\begin{abstract}
Abstrak
Pertumbuhan ekonomi Indonesia di negara maju dan berkembang membawa pendapatan kapita penduduk Indonesia juga meningkat, menyebabkan standar hidup penduduk semakin meningkat. Hal tersebut dipengaruhi oleh pola perilaku belanja seseorang termasuk ibu rumah tangga sebagai manajemen keuangan keluarga, selain tempat belanja yang nyaman dan memberikan semua kebutuhan konsumen mempengaruhi perilaku konsumen. Dalam Hukum Islam, salah satu fungsi harta sebagai perhiasan, harta dunia perhiasan hanya bersifat sementara dan untuk alasan itu, sebagai seorang Muslim harus dapat memanfaatkan properti sebaik mungkin untuk menyembah Allah SWT

Kata Kunci : Perilaku Konsumen, Ibu Rumah Tangga, Hukum Islam

PENDAHULUAN

Ketika Adam as turun ke atas panggung dunia banyak dari segenap manusia telah disongsong oleh berabgai macam problema. Pemenuhan kebutuhan hidup dan pengenalan berbagai sarana serta tata cara pencapaiannya lantara keadaan serba berkecukupan hanya ada di dalam surga. Allah berfirman dalam QS. Thaha (20); 117119 :

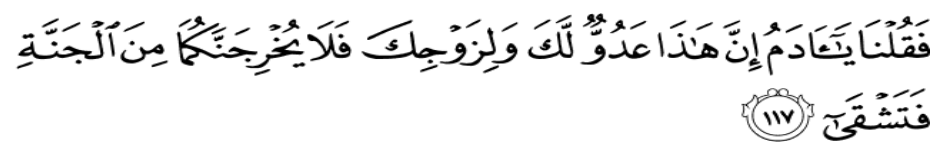




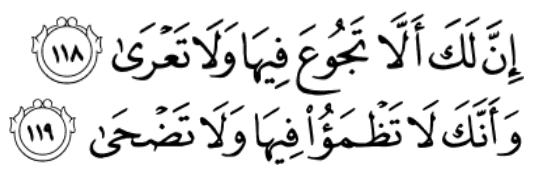

Terjemahannya :

Maka kami berkata "Hai Adam, sesungguhnya ini (Iblis) adalah musuh bagimu dan bagi istrimu, maka sekali-kali janganlah sampai ia mengeluarkan kamu berdua di surge yang menyebabkan kamu menjadi celaka. Sesungguhnya kamu tidak akan kelaparan di dalamnya dan tidak akan telanjang. Dan sesungguh-nya kamu tidak akan merasa dahaga dan tidak pula akan ditimpa terik matahari di dalamnya. ${ }^{1}$

Ayat ini menjelaskan akan adanya suatu beban yang begitu berat yang harus di emban oleh manusia di dunia. Jika terusir dari surga, lantaran mereka harus dapat memenuhi berbagai kebutuhan hidupnya yang antara lain pangan, sandang dan papan sesuai dengan tuntutan situasi dan kondisi dunia tempat dimana manusia hidup dan berusaha.

Seiring kemajuan ekonomi yang pesat ditambah masuknya globalisasi industri barang-barang yang mewah dan yang ber-merek seperti pakaian, sepatu, tas (fashion), makanan, kerajinan, minuman dan sebagai-nya. Kemajuan tersebut membuat berbagai perubahan-perubahan yang menyangkut hampir secara keseluruhan bidang kehidupan. Perubahan tersebut memberikan dampak terhadap pola kehidupan di masyarakat, kebiasaan, adat, tradisi, yang lama sudah mulai ditinggalkan secara perlahanlahan. Hal tersebut diiringi dengan tingkat kompleksitas masyarakat yang lebih tinggi, salah satunya adalah menyebabkan daya beli serta perilaku konsumtif masyarakat bertambah. Daya beli tersebut menyebabkan pusat perbelanjaan bersaing menjual produknya untuk mendapatkan keuntungan. Ber-bagai cara dilakukan pusat perbelanjaan

\footnotetext{
${ }^{1}$ Departemen Agama RI, Al-Qur'an dan Terjemahannya, (Bandung, PT. Syamil Cipta Media, 2004), h. 320.
} 
tersebut misalnya memberikan harga diskon pada produk atau item yang dijual. Hal ini semakin membuat masyarakat untuk terus berperilaku konsumtif dan memenuhi kepuasan pribadi. Perilaku konsumtif ini akan terus ada dan mengakar dalam gaya hidup, sedangkan gaya hidup sendiri harus ditunjang oleh financial yang memadai.

Pada akhirnya perilaku konsumtif bukan saja berdampak pada ekonomi namun juga pada kehidupan sosial. Perilaku kon-sumtif ini hampir terjadi pada semua lapisan masyarakat. Tidak hanya pada orang dewasa (ibu rumah tangga, PNS, pengusaha, swasta) para remaja dan sebagainya.

Pertumbuhan ekonomi Indonesia yang maju dan berkembang membawa pendapatan perkapita penduduk Indonesia ikut meningkat sehingga menyebabkan taraf hidup penduduknya semakin sejahtera. Hal ini terimbas kepada pola prilaku belanja seseorang, selain itu tempat-tempat belanja yang nyaman dan menyediakan segala kebutuhan konsumen.

Setiap individu serta rumah tangga memiliki kebutuhan dalam kehidupan seharihari. Kebutuhan mereka akan ber-beda-beda dengan individu dan rumahtangga lainnya lainnya. Kebutuhan tersebut ber-kaitan dengan konsumsi yang pastinya memiliki fungsi dan manfaat tersendiri. Ibu Rumah Tangga sebagai pengatur yang mengurus kebutuhan konsumsi tersebut mempunyai tugas yang tidak mudah, karena di dalam rumah tangga itu terdiri dari bebe-rapa individu yang mempunyai kebutuhan sendirisendiri yang tidak terlepas dari konsumsi. Konsumsi dilakukan manusia untuk memenuhi kebutuhan baik itu berupa kebu-tuhan primer maupun sekunder. Oleh karena itu para ibu harus lebih bijak dalam memilih kebutuhan mana yang paling utama dari suatu barang serta yang mempunyai manfaat maupun kegunaan agar tidak terjadinya tindakan pemborosan. Pusat perbelanjaan seperti di Mall tidak jarang juga terdapat banyak barang-barang diskon, sehingga membuat para ibu sering menjadi kurang kontrol terhadap dirinya dan berbelanja secara berlebihan tanpa memikirkan kebutuh an maupun kegunaan dari barang-barang yang hendak dibelinya.

Ibu rumah tangga salah satu orang yang merupakan konsumen yang terbesar melakukan prilaku konsumtif, sebagai pengelola keuangan dalam rumah tangga 
dianggap sebagai sasaran pasar yang paling menguntungkann sehingga ibu-ibu rumah tangga yang ada dikota-kota besar maupun di kota-kota kecil membeli. Selain juga merupakan kebutuhan pokok juga membeli dilakukan karena alasan-alasan lain seperti mengikuti mode, mencoba produk baru, tergiur dengan potongan-pontangan harga, hadiah dan ingin memperoleh pengakuan sosial dan sebagainya.

Ibu rumah tangga yang berperilaku konsumtif rela mengeluarkan uangnya untuk menjaga gengsi pada kelompoknya yang telah melahirkan suatu kelompok sosial yang konsumtif. Ini merupakan ciri masyarakat modern. Agar tetap eksis dalam lingkungan pergaulannya.

Kota Palopo sebagai kota yang stra-tegis untuk berkembangnya pusat-pusat berbelanjaan, mall-mall yang dapat memancing kaum konsumtif untuk datang berkunjung di tempat tersebut. Mall sebagia tempat sarana pemenuhan kebutuhan hidup yang serba ada yang didesain menarik, dicat mencolok dengan cahaya lampu yang gemerlap, bau harum yang khas, ditambah rasa sejuk dan nyaman sehingga setiap orang ingin selalu datang ke sana. Ibu rumah tangga yang ada di Kota Palopo juga termasuk salah satu konsumen yang sering mengunjungi pusat-pusat per-belanjaan atau mall. Selain untuk berbelanja bulanan untuk memenuhi kebutuhan pokok juga dijadikan tempat refreshing sekedar untuk menghilangkan kepengatan atau isti-lah sekarang datang ke Mall untuk mencuci mata. Sehingga ibu-ibu rumah tangga yang tadinya tidak berniat untuk membeli kebutuhan-kebutuhan diluar kebutuhan pokoknya akhirnya lahir sehingga butuh pemenuhan gaya hidup. Untuk memenuhi gaya hidup, seseorang atau ibu rumah tangga akan melahirkan perbuatan konsumtif meskipun bertolak belakang dengan realitas kebutuhan dan kemampuan keluarga yang dimilikinya. Realitas yang terjadi pada masyarakat kebiasaan belanja dengan peri-laku konsumtif yang dilakukan masyarakat untuk menunjukkan bahwa mereka dapat mengikuti mode yang sedang beredar dan berkembang. ${ }^{2}$ Begitupun dengan budaya konsumtif yang lahir dari akibat tingginya produksi, distribusi dan peredaran produk barang dan jasa beserta

\footnotetext{
${ }^{2}$ Anonim, http://amin127.wordpress, di akses pada tanggal 25 April 2015.
} 
iklan-iklan produksi yang banyak mempengaruhi pola pikir masyarakat sehingga budaya konsumtif akhirnya lahir sebagai bentuk pemenuhan gaya hidup. ${ }^{3}$

\section{KONSEP PERILAKU KONSUMTIF}

Sebagai makhluk sosial, seorang indi-vidu sejak lahir hingga sepanjang hayatnya senantiasa berhubungan dengan individu lainnya atau dengan kata lain melakukan relasi interpersonal. Dalam relasi interpersonal itu ditandai dengan berbagai aktivitas tertentu, baik aktivitas yang dihasil-kan berdasarkan naluriah semata atau justru melalui proses pembelajaran tertentu. Ber-bagai aktivitas individu dalam relasi interpersonal ini biasa disebut perilaku sosial, untuk memahami perilaku sosial indi-vidu, dapat dilihat dari kecenderungan-kecenderungan ciri-ciri respon interpersonal-nya, yang terdiri dari: (1) Kecenderungan Peranan (Role Disposition); yaitu kecen-derungan yang mengacu kepada tugas, kewajiban dan posisi yang dimiliki seorang individu, (2) Kecenderungan Sosiometrik (Sociometric Disposition); yaitu kecen-derungan yang bertautan dengan kesukaan, kepercayaan terhadap individu lain, dan (3) Ekspressi (Expression Disposition), yaitu kecenderungan yang bertautan dengan eks-presi diri dengan menampilkan kebiasaan-kebiasaan khas (particular fashion). ${ }^{4}$

Menurut Kluytmans perilaku adalah merupakan perbuatan/tindakan dan perkataan seseorang yang sifatnya dapat diamati, digambarkan dan dicatat oleh orang lain ataupun orang yang melakukannya sedang sosial adalah keadaan dimana terdapat kehadiran orang lain. Perilaku sosial adalah perilaku yang terjadi dalam situasi sosial, yakni bagaimana orang berpikir, merasa dan bertindak karena kehadiran orang lain. ${ }^{5}$ Perilaku yang dilakukan oleh individu dapatlah dicermati oleh individu yang lain, begitu pula dalam berkonsumsi. Perilaku konsumen adalah proses pengambilan kepu-

${ }^{3}$ Evika Febriana Pratiwi, Gaya Hidup dan Perilaku Konsumtif Mahasiswa dalam Perspektif Status Sosial Ekonomi Orangtua, Skripsi UN Malang, 2012.

${ }^{4}$ Krech et. al. Individual In Societ.( Tokyo : McGraw-Hill Kogakasha: 1962), p. 172

5 Kluytmans, Frits. Perilaku Manusia ( Bandung : Refika Aditam 2006), h. 84 
tusan dan aktivitas individu secara fisik dilibatkan dalam mengevaluasi, memper-oleh, menggunakan atau dapat memperguna-kan barang atau jasa. ${ }^{6}$

Menurut Rosandi, perilaku konsumtif adalah suatu prilaku membeli yang tidak didasarkan pada pertimbangan yang rasio-nal, melainkan karena adanya keinginan yang sudah mencapai pada taraf yang sudah tidak rasional lagi. ${ }^{7}$ Sabirin mendefinisikan perilaku konsumtif adalah sebagai suatu keinginan dalam mengkonsumsi barang-barang yang sebenarnya kurang dibutuhkan secara berlebihan untuk mencapai kepuasan maksimal. ${ }^{8}$ James F. Engel mendefinisikan prilaku konsumtif adalah sebagai tindakan-tindakan individu yang secara langsung terlibat dalam usaha memperoleh dan menggunakan barang-barang jasa ekonomis termasuk proses pengambilan keputusan yang mendahului dan meentukan tindakan- tindakan tersebut. ${ }^{9}$ Dari definisi dikemukakan oleh beberapa penulis di atas maka peneliti dapat menyimpulkan bahwa prilaku konsumtif adalah suatu prilaku konsumen yang dilakukan seseorang yang bersifat boros dan berlebihan yang lebih mendahulukan keinginan daripada kebutuhan dan tidak ada skala prioritas serta terencana.

\section{ASPEK-ASPEK PERILAKU KONSUMTIF}

Istilah konsumtif biasanya digunakan pada masalah yang berkaitan perilaku konsumen dalam kehidupan manusia. Dewasa ini salah satu gaya hidup konsumen yang cenderung terjadi di dalam masyarakat adalah gaya hidup yang menganggap materi sebagai sesuatu yang dapat mendatangkan kepuasan tersendiri. Gaya hidup seperti ini dapat menimbulkan adanya gejala konsum-tifisme, sedangkan konsumtifisme dapat didefinisikan sebagai pola hidup individu atau masyarakat yang mempunyai keinginan

\footnotetext{
${ }^{6}$ Loudon, D.L, dan Della Bitta, A.J, Consumer Behavior: Concepts and Application, (Singapore: Mc.Grow-Hill, Inc: 1993), h.

7 Andika Filona Rosandi, Perbedaan Prilaku Konsumtif antara Mahasiswa Pria dan Wanita di Unviersitas Katolik Atma Jaya (Jakarta, Skripsi, 2004) h. 22

${ }^{8}$ Sabirin (dalam Meida Devi Wardhani), Hubungan antara Konformitas dan Harga Diri dengan Prilaku Konsumtif Pada Remaja Putri. (Surakarta, Skripsi Universitas Sebelas Maret 2013) h.31

9 James F. Engel, Roger D.B Lachwell, Paul W. Miniard, Consumer Behavior (7th.ed) Harcourt Brace College Publisher Orlando, 1995, h. 29. (Penerjemah Budiyanto) Jakarta : Binarupa Aksara.
} 
untuk membeli atau menggunakan barang dan jasa yang kurang atau tidak dibutuhkan. Aspek-aspek yang berhubungan dengan perilaku konsumtif yaitu:

1. Aspek adanya suatu keinginan meng-konsumsi secara berlebihan

2. Pemborosan, prilaku konsumtif yang memanfaatkan nilai uang lebih besar dari nilai produknya untuk barang dan jasa yang bukan menjadi kebutuhan pokoknya. Perilaku ini hanya ber-dasarkan pada keinginan untuk mengkonsumsi barang-barang yang sebe-narnya kurang diperlukan secara berlebihan untuk mencapai kepuasan yang maksimal.

3. Inefesiensi biaya, pola konsumsi sese-orang terbentuk pada usia remaja yang biasanya mudah terbujuk rayuan iklan, suka ikut-ikutan teman, tidak realistis dan cenderung boros dalam mengguna-kan uangnya sehingga menimbulkan inefesiensi biaya. Pergerakan kebutuhan. Pengambilan keputusan memberi barang dengan mempertimbangkan banyak hal seperti faktor harga, faktor kualitas, faktor manfaat, faktor merk.

4. Emosional, motif pembelian barang ber-kaitan dengan emosi seseorang. Biasa-nya konsumen membeli barang hanya karena pertimbangan kesenangan indera atau bisa juga ikut-ikutan. ${ }^{10}$

Keinginan masyarakat dalam era kehidupan yang modern untuk mengkon-sumsi sesuatu tampaknya telah kehilangan hubungan dengan kebutuhan yang sesungguhnya. Membeli saat ini sering kali dilaku-kan secara berlebihan sebagai usaha seseorang untuk memperoleh kesenangan atau kebahagiaan, meskipun sebenarnya kebahagiaan yang diperoleh hanya bersifat semu.

Menurut Swastha dan Handoko peri-laku konsumen merupakan kegiatan individu yang secara langsung ter-libat dalam men-dapatkan dan menggunakan barang dan jasa termasuk didalamnya proses pengambilan keputusan dan penentuan kegiatankegiatan tersebut. Ada dua elemen penting dari arti perilaku konsumen itu: 1) proses

\footnotetext{
${ }^{10}$ Basu Swastha DH dan T. Hani Handoko, Manajemen pemasaran, Analisa Perilaku Konsumen, (Liberty, Jogyakarta. 1997), h. 64
} 
peng-ambilan keputusan, dan 2) kegiatan phisik, yang semua ini melibatkan individu dalam menilai, mendapatkan, dan mempergunakan barang-barang dan jasa-jasa ekonomis. $^{11}$

Perilaku konsumen akan menentukan proses pengambilan keputusan dalam pembelian mereka. Proses tersebut merupakan sebuah pendekatan penyelesaian masalah pada kegiatan manusia untuk membeli suatu barang atau jasa dalam memenuhi keinginan dan kebutuhannya. Antara kebutuhan dan keinginan terdapat suatu perbedaan. Kebu-tuhan bersifat naluriah. Orang yang merasa lapar, tak perlu diberitahukan bahwa ia membutuhkan makanan. Secara naluriah ia akan mencari barang-barang yang dapat dimakan. Tetapi keinginan merupakan kebu tuhan buatan, yakni kebutuhan yang di-bentuk oleh lingkungan hidupnya, seperti lingkungan keluarga, tempat kerja, kelom-pok sosial, tetangga, dan sebagainya

Menurut Wagner ${ }^{12}$ ada dua faktor yang mempengaruhi keputusan pembelian seseorang. Faktor pertama adalah sikap orang lain, faktor ini dapat mengurangi alternatif yang disukai seseorang tetapi tergantung dari intensitas sikap negatif pihak lain terhadap alternatif konsumen dan motivasi konsumen untuk tunduk pada keinginan orang lain. Faktor kedua ialah situasi yang tidak terduga seperti seseorang yang pernah dikecewakan sehubungan dengan produk yang dibelinya dalam keper-luan lain yang

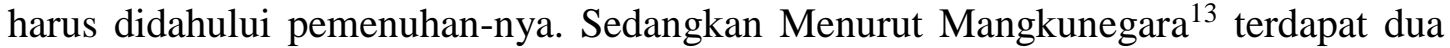
kekuatan yang mempengaruhi prilaku konsumtif yaitu :

1. Kekuatan sosial budaya.

Budaya maksudnya mengacu pada nilai, gagasan, simbol-simbol lain yang bermakna dan akan membantu individu untuk berkomunikasi, melakukan penafsiran dan evaluasi sehingga anggota masyarakat. Kelas sosial artinya sebagai suatu kelompok

\footnotetext{
11 Ibid Skripsi

12 Wagner, Gaya Hidup "Shopping Mall” sebagai bentuk prilaku konsumtif Pada remaja perkotaan.

${ }^{13}$ Mangkunegara, A. Anwar Prabu, Perilaku Konsumen, (PT Eresco: Bandung; 1998), h.
} 
yang terdiri dari sejumlah orang yang mempunyai kedudukan seimbang dalam masyarakat. Ada tiga golongan kelas sosial :

a. Golongan atas, yang termasuk peng-usaha dan pejabat tinggi

b. Golongan menengah, pegawai ins-tansi pemerintah dan pengusaha menengah, pegawai instansi peme-rintah dan pengusaha menengah

c. Golongan bawah seperti buruh pabrik, pegawai rendah, tukang becak dan pedagang kecil

Makin ke atas status ekonomi sese-orang, makin memungkinkan adanya peluang mengkonsumsi barang dan jasa secara lebih banyak, lebih lengkap, lebih mahal. ${ }^{14}$ Keluarga dapat didefinisikan sebagai suatu unit masyarakat yang terkecil yang peri-lakunya sangat mempengaruhi dalam peng-ambilan keputusan membeli.

2. Kekuatan Faktor Psikologis antara lain :

a. Motivasi: merupakan kekuatan yang terdapat dalam diri individu yang menyebabkan individu tersebut ber-tindak dan berbuat.

b. Persepsi: seseorang termotivasi akan siap bereaksi, bagaimana orang telah dimotivasi bertindak adalah dipenga-ruhi oleh persepsinya mengenai situasi

c. Konsep diri adalah: Cara bagaimana seseorang melihat dirinya sendiri dalam waktu tertentu sebagai gamba-ran tentang apa yang dipikirkan

d. Kepribadian: suatu bentuk dari sifat-sifat yang ada pada individu yang sangat menentukan prilakunya. Peri-laku konsumen sangat ditentukan oleh faktor internal dan faktor eks-ternal dan dirinya.

Adapun faktor penunjang terjadinya perilaku konsumtif menurut Zumrotin, perilaku konsumtif ditunjang beberapa faktor, antara lain :

a. Naiknya pendapatan.

Perkembangan bidang ekonomi mem-bawa dampak pada masyarakat. Salah satu-nya adalah naiknya pendapat tikda hanya dalam mutu dan jumlah tetapi juga

\footnotetext{
${ }^{14}$ Philip Kottler, Manajemen Pemasaran : Analisis Perencanaan; Implementasi dan Pengendalian Penerjemah Wasanah J. Jakarta Erlangga, 1994) h. 51
} 
ragam-nya. Misalnya masyarakat modern cende-rung mengkonsumsi barang-barang yang bermerk.

b. Iklan

Media massa berfungsi mengkon-sumsi suatu produk kepada masyarakat dengan iklannya. Iklan merupakan alat produsen untuk mempromosikan produknya. Iklan yang gencar akan megakibatkan rasa ingin tahu pada masyarakat, rasa ingin tahu ini terobati manakala masyarakat tahu konsumen telah memahami atau memiliki produk tersebut.

c. Westerenisasi.

1. Westernisasi adalah sebuah arus besar yang mempunyai jangkauan politik, sosial, Dampak negatifnya, antara lain :

a) Perilaku hidup yang boros dan akan menimbulkan kecemburuan sosial, karena orang akan membeli semua barang yang diinginkan tanpa memikirkan harga barang tersebut murah atau mahal. Barang tersebut diperlukan atau tidak, sehingga bagi orang yang tidak mampu mereka tidak akan sanggup untuk mengikuti pola hidup seperti itu

b) Mengurangi kesepakatan untuk menabung

c) Cenderung tidak memikirkan ke-utuhan yang akan datang

\section{HARTA DALAM ISLAM}

Secara umum, tugas kekhalifahan manusia adalah tugas mewujudkan kemakmuran dan kesejahteraan dalam hidup dan kehidupan (Al-An'aam: 165) serta tugas pengabdian atau ibadah dalam arti luas (adz-Dzaariyaat : 56). Untuk menunaikan tugas tersebut, Allah Swt memberi manusia dua anugerah nikmat utama, yaitu manhaj alhayat " sistem kehidupan " dan wasilah al-hayat" sarana kehidupan . Manhaj al-hayat adalah seluruh aturan kehidupan manusia yang bersumber kepada Al-Qur'an dan Sunnah Rasul. Aturan tersebut berbentuk keharusan melakukan atau sebaiknya melakukan sesuatu, juga dalam bentuk larangan melakukan atau sebaliknya 
meninggalkan sesuatu. Aturan tersebut dikenal sebagai hukum lima, yakni wajib, sunnah, mubah, makruh, atau haram.

Aturan-aturan tersebut dimaksudkan untuk menjamin keselamatan manusia sepanjang hidupnya, baik yang menyangkut keselamatan agama, keselamatan diri (jiwa dan raga), keselamatan akal, keselamatan harta benda, maupun keselamatan nasab keturunan. Hal-hal tersebut merupakan kebutuhan pokok atau primer.Pelaksanaan Islam sebagai way of life secara konsisten dalam semua kegiatan kehidupan, akan melahirkan sebuah tatanan kehidupan yang baik, sebuah tatanan yang disebut sebagai hayatan thayyibah (An-Nahl : 97).

Sebaliknya, menolak aturan itu atau sama sekali tidak memiliki keinginan mengaplikasikannya dalam kehidupan, akan melahirkan kekacauan dalam kehdupan sekarang, ma'isyatan dhanka atau kehidupan yang sempit, serta kecelakaan diakhirat nanti (Thaahaa : 124 -126).Aturan-aturan itu juga diperlukan untuk mengelola wasilah al-hayah atau segala sarana dan prasarana kehidupan yang diciptakan Allah SWT untuk kepentingan hidup manusia secara keseluruhan. Wasilah al-hayah ini dalam bentuk udara, air, tumbuh-tumbuhan, hewan ternak, dan harta benda lainnya yang berguna dalam kehidupan. Adapun fungsi dan kedudukan Harta dalam Islam, yaitu :

1. Fungsi Harta dalam Islam

Fungsi harta bagi manusia sangat banyak. Harta dapat menunjang kegiatan manusia. Selain harta juga salah satu keperluan pokok manusia dalam menjalani kehidupan di dunia. Oleh karena itu manusia selalu berusaha untuk memilikinya dan menguasainya dengan berbagai macam cara, baik yang dilarang oleh syara' (hukum islam), hukum negara, atau ketetapan yang disepakagi oleh manusia itu sendiri.

Orang yang memperoleh harta dengan cara yang halal dan baik biasanya memfungsikan harta dengan hal-hal yang ber-manfaat. Sebaliknya orang yang mem-peroleh harta dengan cara yang kurang baik atau tidak halal biasanya memfungsikan harta dengan hal-hal yang kurang ber-manfaat hanya untuk kesenangan dunia saja. 
Adapun fungsi harta sesuai ketentuan syara ${ }^{15}$ adalah :

a. Sebagai kesempurnaan ibadah seperti shalat memerlukan kain untuk menutup aurat

b. Memelihara dan meningkatkan ke-imanan dan ketaqwaan kepada Allah swt sebagaimana kefakiran mendekat-kan kepada kekufuran (kafir)

c. Meneruskan estafet kehidupan, agar tidak meninggalkan generasi yang lemah

d. Menyeimbangkan antara kehidupan dunia dan akhirat

e. Bakal mencari dan mengembangkan ilmu

f. Keharmonisan hidup bernegara dan bermasyarakat misalnya orang kaya memberikan pekerjaan kepada orang miskin.

Harta merupakan kebutuhan inti dalam kehidupan dimana manusia tidak akan bisa terpisah darinya. Secara umum, harta merupakan sesuatu yang disukai manusia, seperti hasil pertanian, perak dan emas, ternak atau barang-barang lain yang ter-masuk perhiasan dunia. Manusia termotivasi untuk mencari harta demi menjaga eksistensinya dan demi menambah kenikmatan materi dan religi, dia tidak boleh berdiri sebagai penghalang antara dirinya dengan harta. Namun, semua motivasi ini dibatasi dengan tiga syarat, yaitu harta dikumpul-kannya dengan cara yang halal, dipergunakan untuk hal-hal yang halal, dan dari harta ini harus dikeluarkan hak Allah dan masyarakat tempat dia hidup.

Harta yang dimiliki setiap individu selain didapatkan dan digunakan juga harus dijaga. Menjaga harta berhubungan dengan menjaga jiwa, karena harta akan menjaga jiwa agar jauh dari bencana dan meng-upayakan kesempurnaan kehormatan jiwa tersebut. Menjaga jiwa menuntut adanya perlindungan dari segala bentuk penganiayaan, baik pembunuhan, pemotongan anggota badan atau tindak melukai fisik.

Harta dalam pandangan Islam pada hakikatnya adalah milik Allah SWT. kemudian Allah telah menyerahkannya ke-pada manusia untuk menguasai harta tersebut melalui izin-Nya sehingga orang tersebut sah memiliki harta tersebut. Adanya

\footnotetext{
${ }^{15}$ Hendi Suhendi, Fiqih Muamalah (Bandung, Gunung Djati Press, 1997) h. 28-30
} 
pemilikan seseorang atas harta kepemilikian individu tertentu mencakup juga kegiatan memanfaatkan dan mengembangkan kepe-milikan harta yang telah dimilikinya tersebut. Setiap muslim yang telah secara sah memiliki harta tertentu maka ia berhak memanfaatkan dan mengembangkan harta-nya. Hanya saja dalam memanfaatkan dan mengembangkan harta yang telah dimiliki-nya tersebut ia tetap wajib terikat dengan ketentuan-ketentuan hukum Islam yang berkaitan dengan pemanfaatan dan pengembangan harta. Sebagaimana dalam QS. Al-Baqarah/2 : 29:

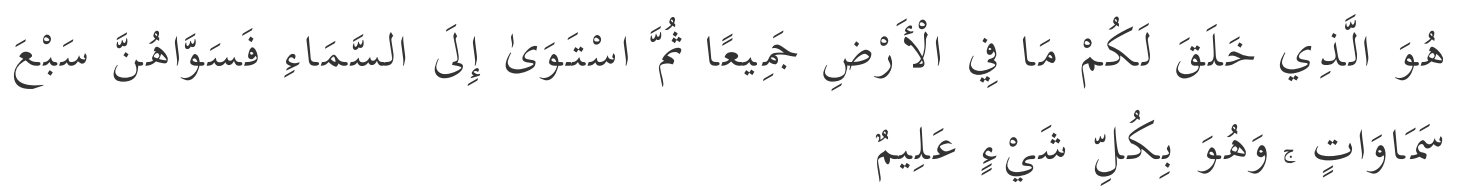

Terjemahnya:

"Dialah Allah yang menjadikan segala yang ada di bumi untuk kamu dan Dia berkehendak (menciptakan) langit, lalu dijadikan-Nya tujuh langit. Dan, dia Maha Mengetahui segala sesuatu “

Dari keterangan di atas, Islam mem-punyai pandangan yang jelas mengenai harta dan kegiatan ekonomi. Pandangan tersebut dapat diuraikan sebagai berikut :

a. Harta adalah milik Allah, manusia bukanlah pemilik mutlak, tetapi dibatasi oleh hak-hak Allah sehingga wajib dikeluarkan zakatnya dan peruntukan ibadah. Allah berfirman QS. Al-Hadid / $57: 7$

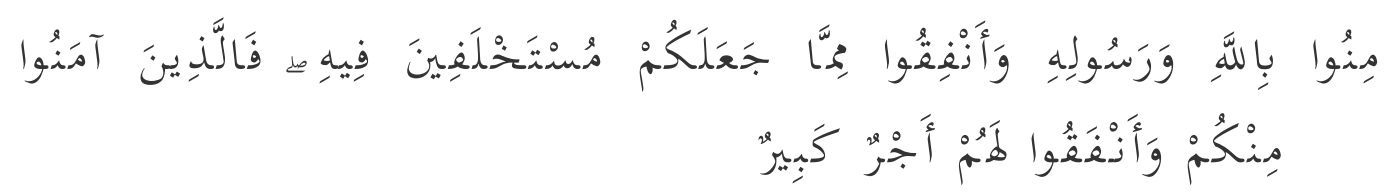

Terjemahnya:

Berimanlah kamu kepada Allah dan Rasulnya dan infakkanlah sebagian dari hartamu yang telah Allah pinjam-kan kepada-Mu. ${ }^{16}$

${ }^{16}$ Ibid, h.538 
b. Harta sebagai sarana untuk memperoleh bekal menuju kehidupan akhirat. Allah berfirman dalam Al-Quran QS. Al-Baqarah 2 : 262

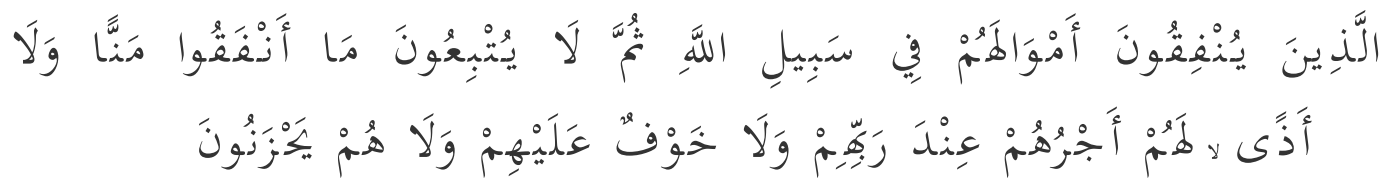

Terjemahnya :

Orang-orang yang menafkahkan harta-nya di jalan Allah, kemudian mereka tidak mengiringi apa yang dinafkah-kannya itu dengan menyebut-menyebut pemberiannya dengan tidak menyakiti (perasaan sang penerima) mereka memperoleh pahala di sisi Tuhan mereka. Tidak ada kekhawatiran terhadap mereka dan tidak pula mereka bersedih hati. ${ }^{17}$

c. Harta sebagai sarana untuk memenuhi kesenangan sebagaimana firman Allah dalam Al-Qur'an QS. Ali Imran 3 : 14

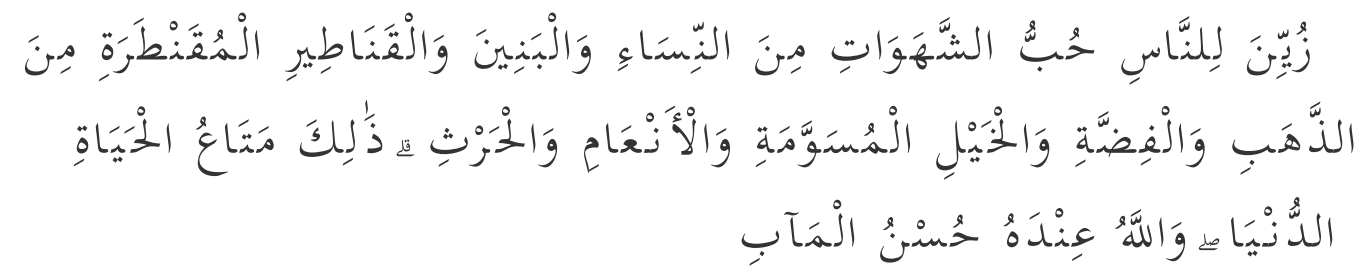

Terjemahnya :

Dijadikan indah pada (pandangan) manusia kecintaan kepada apa-apa yang diingini, yaitu : wanita, anak-anak, harta yang banyak dari jenis emas, perak, kuda pilihan, binatang-binatang ternak dan sawah ladang. Itulah kesenangan hidup di dunia dan di sisi Allah-lah terdapat kembali yang baik (surga). ${ }^{18}$

d. Harta sebagai ujian, sebagaimana pada QS. Ath-Taghabun/64:15

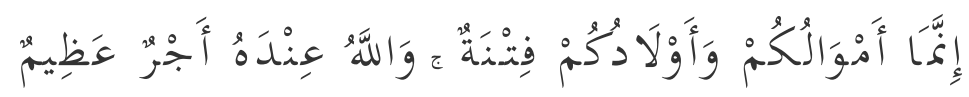

${ }^{17}$ Ibid, h.44

${ }^{18}$ Ibid, h. 51 
Terjemahnya:

Sesungguhnya harta dan anak-anak kalian hanyalah cobaan (bagi kalian) di sisi Allah-lah pahala yang besar. ${ }^{19}$

e. Harta sebagai perhiasan, harta merupakan perhiasan dunia yang hanya bersifat sementara dan untuk itulah maka sebagia seorang muslim hendaknya dapat memanfaatkan harta dengan sebaik-baiknya untuk beribadah kepada Allah swt . QS. Al-Kahfi 18:46

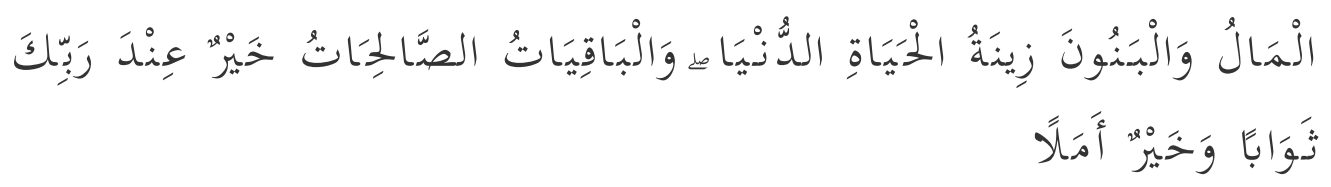

Terjemahnya :

Harta dan anak-anak adalah perhiasan kehidupan di dunia. ${ }^{20}$

f. Harta sebuah nikmat ketika dimanfaat-kan oleh orang-orang yang shalih sebagaimana dalam hadis: Sebaik-baiknya harta adalah yang ada pada serang yang shaleh (HR. Ahmad). Harta merupakan suatu kebutuhan pokok manusia dalam menjalani kehidupan di dunia. Oleh karena itu, Allah swt memerintahkan manusia untuk berusaha mencari harta dan memilikinya dengan cara yang halal dan tidak melanggar norma-norma agama. Di samping itu harta bukanlah sebagai tujuan tetapi merupakan alat untuk menyempurnakan kehidupan dan untuk mencapai keridhaan Allah swt.

\section{DAFTAR PUSTAKA}

Andika Filona Rosandi, Perbedaan Prilaku Konsumtif antara Mahasiswa Pria dan Wanita di Unviersitas Katolik Atma Jaya Jakarta, Skripsi, 2004.

Basu Swastha DH dan T. Hani Handoko, Manajemen pemasaran, Analisa Perilaku Konsumen, Liberty, Jogyakarta. 1997.

\footnotetext{
${ }^{19}$ Ibid, h.557
}

${ }^{20}$ Ibid, h. 299. 
Departemen Agama RI, Al-Qur'an dan Terjemahannya, Semarang, Toha Putra, 1989.

Evika Febriana Pratiwi, Gaya Hidup dan Perilaku Konsumtif Mahasiswa dalam Perspektif Status Sosial Ekonomi Orangtua, Skripsi UN Malang, 2012.

Hendi Suhendi, Fiqih Muamalah, Bandung, Gunung Djati Press, 1997.

James F. Engel, Roger D.B Lachwell, Paul W. Miniard, Consumer Behavior $\left(7^{\text {th }}\right.$.ed) Harcourt Brace College Publisher Orlando, 1995, Penerjemah Budiyanto, Jakarta : Binarupa Aksara.

Kluytmans, Frits. Perilaku Manusia, Bandung : Refika Aditam 2006

Krech et. al. Individual In Societ. Tokyo : McGraw-Hill Kogakasha: 1962.

Loudon, D.L, dan Della Bitta, A.J, Consumer Behavior: Concepts and Application, Singapore: Mc.Grow-Hill, Inc: 1993.

Mangkunegara, A. Anwar Prabu, Perilaku Konsumen, PT Eresco: Bandung;1998.

P.Kottler, Manajemen Pemasaran : Analisis Perencanaan; Implementasi dan Pengendalian Penerjemah Wasanah J. Jakarta Erlangga, 1994.

Sabirin (dalam Meida Devi Wardhani), Hubungan antara Konformitas dan Harga Diri dengan Prilaku Konsumtif Pada Remaja Putri. Surakarta, Skripsi Universitas Sebelas Maret 2013.

Wagner, Gaya Hidup "Shopping Mall" sebagai bentuk prilaku konsumtif pada remaja perkotaan. Skripsi

Zumrotin K. Susilo. Penyambung Lidah konsumen. Jakarta, YLKI dengan Puspa Swara : 1996 